\title{
Diabos e diabinhos: uma história social e carnavalesca dos sentidos da roupa
}

Poliana dos Santos ${ }^{1 *}$ ${ }^{1}$ Universidade Federal de Alagoas, Delmiro Gouveia/AL - Brasil

\section{RESUMO}

Este artigo tem como objetivo compreender os sentidos simbólicos da roupa no começo da República brasileira, enfocando a fantasia carnavalesca de diabo, que ganhou popularidade no século XIX e foi praticamente abolida no século XX. Para isso, pretendemos elaborar um estudo comparativo dos significados da vestimenta por meio da literatura, da crônica jornalística e da caricatura. Os textos "A vingança" e "O moleque" de Lima Barreto serão basilares para entender como os valores sociais se apresentam na forma da roupa, apresentando-se como elementos-chave nesta investigação. A discussão será feita a partir de uma abordagem cultural da história e da análise literária.

Palavras-chave: história; carnaval; diabinho; Lima Barreto.

\section{Devils and little devils: a Social History of the clothing in the Brazilian Carnival}

\section{ABSTRACT}

This paper aims to examine the symbolical meanings of clothing in the beginning of the Brazilian Republic by focusing on the devil carnival costume that became popular throughout 19th century and ended up being abolished in the 20th century. It intends to present a comparative study of the meanings of costume that can be found in Brazilian literature, journalistic chronicle and caricature. Therefore, two texts written by Lima Barreto, "A vingança" and "O moleque", are pivotal in this study in order to understand how social rules were present in carnival costumes. Analysis is based on a cultural approach of History and Literature.

Keywords: history; Carnival; little devil; Lima Barreto.

DOI: http://dx.doi.org/10.1590/2237-101X02104305

Artigo recebido em 12 de junho de 2018 e aceito para publicação em 6 de março de 2019.

* Professora da Universidade Federal de Alagoas / Departamento de História, campus Sertão, Delmiro Gouveia/AL - Brasil. E-mail: poliana.stos@hotmail.com. ORCID: https://orcid.org/0000-0002-6941-4565. 


\section{Diablos y diablillos: una historia social y carnavalesca de los sentidos de la ropa}

\section{RESUMEN}

Este artículo tiene como objetivo comprender los sentidos simbólicos de la ropa en el comienzo de la República brasileña, enfocando la fantasía carnavalesca de diablo, que ganó popularidad en el siglo XIX y fue prácticamente abolida en el siglo XX. Para eso, pretendemos abordar un estudio comparativo de los significados de la vestimenta por medio de la literatura, de la crónica periodística y de la caricatura. Los textos "A vingança" y "O moleque" de Lima Barreto serán fundamentales para entender cómo los valores sociales se muestran en la forma de la ropa, manifestándose como elementos claves en esta investigación. La discusión será hecha a partir de un abordaje cultural de la historia y del análisis literario.

Palabras clave: historia; carnaval; diablillo; Lima Barreto.

\section{Literatura e resistência}

Este artigo pretende analisar os significados metafóricos da roupa no começo da República brasileira, partindo de um exame comparativo entre a literatura, representaçôes gráficas e outros gêneros textuais. A focagem será direcionada, em especial, para o disfarce carnavalesco de diabinho. Para tanto, foram selecionados o conto "O moleque" e a crônica "A vingança (história de carnaval)" de Lima Barreto. O autor constrói uma narrativa engajada e de resistência, tomando o período de carnaval e o espaço suburbano como aspectos centrais na intriga da sua história. A fantasia de diabinho, usada pela personagem principal do conto, vai se mostrar carregada de potência simbólica e de forte sentido cognitivo. Também faremos uso de fontes jornalísticas e iconográficas, a exemplo das caricaturas da revista Fon-Fon!, que abordam a alegoria mefistofélica. Buscamos compreender como a obra do escritor dialoga com outras linguagens de sua época, elaborando um discurso contraideológico, marcado por uma consciência histórica. Participarão desse diálogo outros cronistas e literatos, como Machado de Assis e João do Rio, alargando ainda mais o espaço de discussão, tornando-o mais plural e rico de significados. Por fim, seguindo as pistas deixadas na ficçáo do autor, pretendemos remontar uma parte da história do carnaval popular, que ainda foi pouco explorada pela crítica.

Num artigo intitulado "Narrativa e resistência", Bosi (2002) explica como a resistência, conceito ligado ao imperativo ético, conjuga-se ao estético por meio de duas formas: enquanto temática e como algo constitutivo da escrita. $\mathrm{O}$ ato de resistir pressupóe um valor,

\footnotetext{
${ }^{1}$ Tanto o conto quanto a crônica estáo localizados em BARRETO, 2010.
} 
um sentimento de bem e de mal, que se realiza na literatura por meio do artifício formal: o foco narrativo, a estilização da linguagem, as práticas da fantasia e da memória. Conforme o crítico literário, diferentemente do homem de ação, cujo valor moral deve ter correspondência com a realidade dos fatos, o escritor possui uma vasta liberdade inventiva, elaborando, segundo a sua subjetividade, as representaçóes e ambiguidades do verdadeiro e do falso. A obra literária se executaria, nesse caso, sob uma tensão entre um “eu/mundo". Desse modo, a reprodução mecânica da vida e suas formas de exploração são recusadas pela ficção em favor de uma existência mais digna. A literatura, como resistência, compóe-se como negação ao discurso ideológico e à mentalidade reinantes.

Essa compreensão da literatura como uma arte engajada, direcionada para o outro, fez parte do universo intelectual de Lima Barreto. Para ele, o literato deveria ser, antes de tudo, "um semeador de ideias, um batedor do futuro" (BARRETO, 2004, p. 304). A escrita sempre foi para Barreto um instrumento contra as injustiças e os preconceitos sociais. Ela é uma arte da militância, cuja função ultrapassa a mera contemplação e a beleza ideal. A literatura teria, por intermédio da forma, um papel maior, isto é, o de ligar a humanidade, promover "a comunhão dos homens e de todas as raças e classes, fazendo com que todos se compreendam, na infinita dor de serem homens, e se entendam sob o açoite da vida, para maior glória e perfeição da humanidade" (BARRETO, 2010, p. 58). Sua concepção corresponde àquela que Sartre (1989) desenvolveu bem mais tarde, a da criação artística como generosidade, como retomada da totalidade do mundo pelos homens.

A tarefa da literatura, consoante a esse raciocínio, é desvendar o mundo e os homens, recorrendo ao leitor para uma consciência histórica, para uma consciência de luta. Essa foi a missão perpetrada pelo escritor brasileiro, que deixou um rico material para entender a sociedade e o Brasil do seu tempo.

Alguns dos atributos formais da resistência, que compóem os textos examinados neste trabalho, são o lúdico, a fantasia e o humor. É expressivo destacar que esses elementos são igualmente correlatos à realidade do universo popular. Segundo Pereira (2017, p. 1-26), a atividade lúdica, como os clubes recreativos, era um fenômeno social do Rio de Janeiro do início do século XX, configurando-se como um forte componente de sociabilidade. Essas organizaçóes não se preocupavam apenas com o divertimento. Elas se espalhavam pelas classes pobres e os subúrbios da capital, misturando o lazer com as lutas por direitos. Muitos operários eram membros desses grêmios, participavam de greves e organizavam bailes para celebrar o Primeiro de Maio. Algumas associaçóes combatiam o preconceito racial, não fazendo distinção de cor e religião entre seus integrantes (PEREIRA, 2010). Davis (1990) já tinha observado essa dimensão do lúdico, explicando como a vida real estava profundamente ligada à diversão carnavalesca, em que as classes populares usavam de sociedades alegres para criticar a ordem social.

Nesse sentido, a faculdade imaginativa se transformava numa expressão cultural e de resistência, que se personificava nos dias foliônicos por meio de disfarces. Os nomes de 
vários grêmios faziam referências à crise inflacionária vivida na República, como Miséria e Fome e Esfolados (CUNHA, 2001, p. 171). Em 1917, o clube Carestia, do Engenho Novo, protestou contra o alto custo de vida, saindo à rua num grosso fandango. À frente do desfile, apresentava-se uma personagem esfarrapada, denominada "Carestia-mor", carregando uma sacola na máo e pedindo ajuda (JORNAL DO BRASIL, 26/1/1917, p. 10).

Segundo Saliba (2002, p. 70), a conduta humorística seria um caráter geral do brasileiro, ajudando-o a lidar com os conflitos sociais num momento de passagem de regime político, a exemplo do que aconteceu com a transição do Império para a República. O humor popular usava da lógica do avesso e do improviso como formas de sobrevivência. O cômico não estava desassociado da experiência das classes inferiorizadas na defesa de seus direitos.

Lima Barreto capta o espírito do momento, ocupando-se, de maneira sensível, da experiência popular, na cidade do Rio de Janeiro, então capital do país. Pobre, negro e marginalizado, o autor escreveu sobre os excluídos, as suas queixas e os preconceitos vivenciados pela gente comum e economicamente humilde. Mas evidenciou igualmente suas táticas, no sentido desenvolvido por Certeau (2014, p. 94-95), ou seja, os improvisos e as possibilidades de confronto diário, encontrados pelas classes pobres.

\section{Evohé! Recordação de um carnaval encarnado}

"O moleque" foi publicado por Lima Barreto, em 1920, no livro Histórias e sonhos, e teve origem a partir de um manuscrito do literato, denominado "A vingança (história de carnaval)". Este original se encontra na Biblioteca Nacional, na coleção do autor. Em 2010, Lilia Moritz Schwarcz reuniu e publicou o conjunto completo de contos do escritor, junto com alguns manuscritos e textos incompletos. É a partir dessa edição que discutimos a obra (BARRETO, 2010).

O conto apresenta aspectos jornalísticos variados, valendo-se de técnicas descritivas e do elemento factual e informativo. Assim, o narrador divaga sobre as designaçóes indígenas de certas regióes do Rio de Janeiro; sobre os subúrbios e suas particularidades, ressaltando a estrutura geográfica do lugar, bem como as suas características sociais e religiosas. Ele também relata a atração que os elementos modernos provocam nos indivíduos pobres, como o cinema e a iluminação; e, enfim, narra um caso de carnaval. Toda essa variedade de assuntos faz dessa narrativa uma estrutura complexa, em que o imaginário se mistura aos fatos históricos, à memória passada e à experiência cotidiana, pondo em questáo para o leitor os limites fronteiriços dos gêneros textuais. Seria um conto ou uma crônica? A composiçáo intrincada do texto é correlata à própria confecção da personagem e da narrativa, que parece simples, mas é carregada de símbolos e conflitos singulares de uma época. $\mathrm{Na}$ análise presente, demos atenção apenas a um dos diversos temas desenvolvidos no conto, visto que ele é central na história: a temática do carnaval. 
O protagonista da história é Zeca, um garoto pobre e negro, de nove anos de idade, que mora no subúrbio de Inhaúma com sua mãe, Felismina, senhora de meia idade que sobrevive como lavadeira. O menino sempre auxiliava sua mãe nos serviços de casa e no de ganho, levando e trazendo as roupas dos fregueses. Zeca tem características psicológicas ambíguas, sendo ao mesmo tempo resignado e imperioso. Essa ambiguidade ajuda a compor uma personagem em tensão, que, apesar de estar numa condição social inferiorizada e de obediência, por ser negro e criança, possui gestos de resistência e de negaçáo. A narrativa do conto é simples. Durante o período carnavalesco, o garoto sai de casa para entregar as roupas para um cliente de sua mãe, o coronel e fazendeiro Castro. No caminho, ele é abordado por algumas crianças que zombavam dele com expressôes "ó moleque!”, “ó negro!", “ó gibi”. Gozaçôes claramente de teor racial. Ao chegar à fazenda, o menino contou ao coronel o que tinha acontecido e este, para abrandar a tristeza do petiz, lhe prometeu uma fantasia de diabinho.

Com efeito, a vestimenta de diabinho se tornaria uma oportunidade para o garoto se vingar da grosseria. E a pândega momesca seria a situação ideal para se pregar uma peça. A especificidade da fantasia revela a intençáo pueril do protagonista, que era provocar susto e medo nos meninos trocistas: um traje vermelho de ganga rala, com uma "máscara apavorante de olhos esbugalhados, língua retorcida e chifres agressivos” (BARRETO, 2010, p. 150). Porém, Felismina, ao ver a fantasia, não compreende a sua utilidade, achando uma bobagem o presente e duvidando da importância que o apetrecho tinha para o filho.

Já na crônica, Lima Barreto faz algumas alteraçóes na história. Os epítetos atribuídos a Zeca eram diferentes, mas com o mesmo conteúdo racista: "mouco" e "macaco". A máscara mefistofélica tinha sido dada por outro personagem, de nome Chico, e o resto dos acessórios foi comprado pelo próprio garoto. A conformação e a incompreensão da mãe com relação à alegoria e à vingança do jovem são apresentadas nesse texto de modo mais intensificado. O narrador chama a atençáo para os gestos e o ato da senhora que, enquanto conversava com o pequeno, lavava e arrumava resignadamente "a roupa de várias famílias conceituadas".

Esse fato comezinho e aparentemente insignificante, notado por um narrador-cronista, atento ao diminuto - o modo como as peças de roupa sáo lavadas -, comunica uma carga histórica de longa duração. No universo autoritário e hierarquizado do regime republicano, contexto da narrativa, a ação trivial da personagem remete ao tipo de ocupação e de relações de trabalho que foram socialmente determinados a boa parcela das mulheres negras. Relaçóes e funçóes estas vinculadas a um sistema secular de escravidáo, que se manteve tão forte quanto violento, mesmo com a abolição. As atividades domésticas e braçais eram as possibilidades de empregos predominantes para a população negra e pobre do período, que, como sabido, foi alforriada sem um projeto social de inclusáo e de igualdade. Mas Lima Barreto náo focaliza apenas o aspecto de sujeiçáo do negro pelo trabalho, mirando também para formas de oposiçấo. Para isso, toma como eixo estético a vestimenta. 
Schwarcz (2017, p. 60) examinou o conto a partir de suas notas biográficas, destacando o episódio em que Feslimina acusa Zeca de ter roubado a máscara. A historiadora faz um paralelo entre o protagonista e a experiência de Lima menino, que foi acusado de furto quando criança. Já Cunha (2001, p. 185-187) examinou a crônica tratando da suspeição do roubo e alargando a análise para a subversão do carnaval. A revanche da personagem remonta aos sentidos políticos da festa, apresentando-se como desafio ao preconceito. Para além dessas interpretaçôes, devemos enfatizar que nos dois textos, mas em particular no conto, Lima Barreto dramatiza os nossos próprios trajes, colocando-os em ambiguidade e apontando-os para novos significados. As roupas se mostram na forma de luta (fantasia), de servidão (a indumentária branca do senhor), da pureza (Zeca usava vestes sempre limpas) e da convençáo burguesa (terno de casimira).

No conto, os valores da vida burguesa são simbolizados no terno de casimira usado pelo protagonista. Roupa velha do coronel Castro e adaptada à criança. $\mathrm{O}$ mundo burguês é apropriado por meio da vestimenta, na busca por uma posiçáo de igualdade e por uma condição respeitável. Tornar-se um igual significava também vestir-se como um igual. Porém, o fato de a peça já estar envelhecida e de o menino portar tamancos surrados de passeio é sintomático das relaçôes desiguais entre as classes e da profunda miséria que separa o garoto do conforto da burguesia. As roupas, que vestem a parte superior do corpo, representam vontade de ascensão; os calçados, mais próximos do chão, simbolizam a realidade em falta. "Em cima dos seus tamancos domingueiros, com o terno de casimira que a caridade do coronel Castro lhe dera e a tesoura de sua mãe adaptara a seu corpo, ele, fascinado, não pensava senão naquele cinema brilhante de luzes e apinhado de povo" (BARRETO, 2010, p. 148).

Entre as diversas representações de roupas, Lima Barreto destaca duas confecções simbólicas. Uma torna-se objeto de protesto e de combate; a outra sinaliza para uma atitude de submissão. De um lado, a roupa de diabinho e a figura do protagonista revelam as agressôes e as angústias que as crianças negras sofriam. Demonstram também a não aceitação do preconceito, as batalhas travadas contra as humilhaçóes e o racismo presentes no universo infantil. Já a indumentária que Feslimina asseava é indicativa dos rebaixamentos a que a população pobre e negra ainda estava sujeita na República. Portanto, eram as roupas de "famílias conceituadas", como as do fazendeiro Castro, que a boa mulher limpava e arrumava, assim como o escravo antes fazia na casa-grande para o seu senhor.

Tal personagem feminina é esquematizada principalmente em função de sua capacidade de agir - viúva que criava sozinha o filho, trabalhadora autônoma e curandeira. Sua aparição no conto está atrelada ao ato de lavar, de remendar as roupas dos fregueses, de retirar dos arames a roupa branca do branco. Mas é preciso destacar que não estamos diante de um mundo psicológico fechado. Feslimina guarda em si uma resistência, explícita na reação titubeante que teve quando o coronel a convidou para morar na fazenda. O retorno à casa-grande significava viver novamente sobre a sombra da escravidáo, era perder a liberdade. 
Do ponto de vista da terceira pessoa, o narrador comenta em tom crítico o significado do titubeio da mãe de Zeca: "uma espécie de Protesto de Posse contra a dependência da escravidão que sofreram durante séculos" (p. 149). O seu cambalear está ligado à memória histórica e aos traumas mnêmicos do cativeiro. Todavia, a postura hesitante da velha deslocava para o garoto a esperança e o campo de luta. É dele que surge uma resposta mais aguerrida, trespassada pela brincadeira e pela ingenuidade.

Já Zeca é caracterizado por seu asseio físico e suas qualidades emocionais. É significativo que o seu corpo seja descrito pelo narrador sob a metáfora da vestimenta - "um pretinho de pele de veludo, macia de acariciar o olhar" (p. 146). Por meio da propriedade do tecido, desenham-se os predicados do garoto como personagem aprazível e sensível. Os seus atributos internos sáo marcados por paradoxos. Ele tem muita doçura e tristeza, é obediente e imperioso, resignado e insistente. Essas qualidades opostas se fundem na criança, constituindo uma personalidade que ainda está sujeita às consequências da escravidão, porém, não se esmorece diante da violência e do racismo. A passagem em que o garoto vai à venda comprar sabáo é relevante para entender o seu temperamento. Ao mesmo tempo em que era estimado por todos no botequim, ele era igualmente provocativo com o balconista, destacando-se entre os demais clientes - "Caixeiro, 'mi' serve já" (p. 147). Sua força interior se difere do conformismo da mãe, que não compreende a alegria do filho e passa a questionar a importância do presente: "para que essas bobagens?" "Isso é para gente rica" (p. 151). A figura materna só toma como necessário o que é da esfera da sobrevivência.

Para Felismina, o negro estava relegado ao mundo físico do trabalho, náo como uma escolha, mas como imposição. Inexistia espaço para as brincadeiras e para a escola. Ela queria ver o filho no colégio, mas Zeca era fundamental no processo laboral. Quem levaria e traria as roupas? Quem faria as compras? A escrita, a leitura e a matemática eram privilégios dos brancos. "Não sabendo ler, escrever e contar, tinha que pedir a 'seu' Frederico, aquele 'branco’ que fora colega de seu marido" (p. 147).

Essa imagem literária criada pelo autor, que informa um processo histórico configurado na duração entre trabalho, escravidáo e preconceito, pode ser notada em outras memórias, temporalidades e gêneros artísticos. Gilberto Gil, em 1984, recorre a ela na música "A mão da limpeza", exprimindo como as relaçóes desiguais e escravocratas que organizaram a sociedade brasileira permanecem vivas até hoje. O compositor também utiliza a roupa e a tarefa doméstica como temática e categoria simbólica para representar as particularidades e ambiguidades históricas e culturais do país, baseadas numa correlação desproporcional de força entre brancos e negros. A canção ironiza igualmente o fato de o negro ser associado preconceituosamente à sujeira, ainda que estivesse disposto socialmente em funções de limpeza. 


\section{A mão da limpeza}

O branco inventou que o negro

Quando não suja na entrada

Vai sujar na saída, ê

Imagina só

Vai sujar na saída, ê

Imagina só

Que mentira danada, ê

$\mathrm{Na}$ verdade a mão escrava

Passava a vida limpando

O que o branco sujava, $\hat{e}$

Imagina só

O que o branco sujava, $\hat{e}$

Imagina só

O que o negro penava, $\hat{e}$

Mesmo depois de abolida a escravidão

Negra é a mão

De quem faz a limpeza

Lavando a roupa encardida, esfregando o chão

Negra é a mão

É a mão da pureza

Negra é a vida consumida ao pé do fogão

Negra é a mão

Nos preparando a mesa

Limpando as manchas do mundo com água e sabão

Negra é a mão

De imaculada nobreza

$\mathrm{Na}$ verdade a mão escrava

Passava a vida limpando

O que o branco sujava, ê

Imagina só

O que o branco sujava, $\hat{e}$

Imagina só

Eta branco sujão

(GIL, 1984) 
Posto isso, a vestimenta demoníaca é bastante simbólica no conto, pois o diabo não é apenas um ser ardiloso, é igualmente um anjo rebelde que enfrentou a maior potestade dos céus. Além disso, é um espírito galhofeiro, representando todas as energias que perturbam e enfraquecem a consciência (CHEVALIER e CHEERBRANT, 1995, p. 337-338). Nesse sentido, o diabo é a representação de rebeldia e de batalha, dada numa relação de força desigual entre aquele que detém o poder e aquele que aparenta subordinação.

O acessório carnavalesco também alude a elementos particulares da história brasileira. Lima Barreto, com perspicácia, traz para o conto uma das fantasias mais antigas do carnaval carioca: o diabinho, considerado por sua popularidade um tipo ou uma entidade carnavalesca, presente desde a segunda metade do século XIX. Os trajes encarnados, os longos chifres e a enorme cauda eram um dos utensílios preferidos das classes pobres do Rio de Janeiro. As vestes confeccionadas com tecido de ganga ou metim de cor vermelha eram o sucesso e o temor da criançada. Quando surgiam na rua os diabretes aos saltos, guinchando, rodopiando e distribuindo rabanada a torto e a direito, todos corriam e fugiam.

Embora o disfarce fosse apreciado por todos os públicos, inclusive por aqueles mais afortunados, a imprensa frequentemente associava a camuflagem diabólica e as diabruras aos negros capoeiras ${ }^{2}$, exigindo que se proibisse o uso da temível máscara. A popularização desse vestuário momesco era vista como negativa pelo jornal e pela polícia. $\mathrm{Na}$ concepção elitista, a apropriação e o gosto do povo pela fantasia faziam com que esta se tornasse bárbara, sinônimo de crime e perversão. Por esse motivo, o indumento mefistofélico foi perseguido e coibido. Um cronista da revista Fon-Fon!, que assinava com o pseudônimo de Dip., expóe claramente essa imagem:

Não houve capoeira, moleque de maus bofes, rebotalho de bodegas e cortiços, que se não fantasiasse de diabinho para exercer suas façanhas cruéis. Alguns, no exagero bruto de suas imaginaçóes de bárbaro, complicavam os trajos, adicionavam-lhe outras cores, outros objetos e ornamentos: tais como mantéus, capuzes, tridentes, bastôes, etc... [...] As mascaradas passaram a ser horrendamente estúpidas, algumas mediam um metro, metro e pouco de tamanho! E eram adornadas de cobras, lagartos, sapos, corujas. Pesavam tanto que lhe era difícil trazê-las por alguns minutos sobre o rosto, carregavam-nas às costas, ou aos ombros!

Era, então, que se lhes percebiam as visagens duras, mas, de assassinos amadores, negralhóes e mulataços de maltas, gentalha de eleições que a política protegia, embrutecidos dos vícios e hóspedes de calabouços, uma horda de bandidos, donde saíram mais tarde os célebres cordóes,

\footnotetext{
${ }^{2}$ A figura do diabo já se fazia presente nas procissões religiosas coloniais, a exemplo das celebraçôes de São Jorge, de Corpus Christi e do sábado de Aleluia. No ritual de Judas, o diabo era responsável pelo enforcamento do discípulo, mas foi no carnaval oitocentista que essa representação tomou novos significados e popularidade. A fantasia carnavalesca adquiriu um teor fortemente racial, sendo associada aos capoeiras e às pessoas negras do Rio de Janeiro. Cf. NEPOMUCENO, 2011.
} 
que se digladiavam a navalha e a revólver. E tanto e tais crimes praticavam esses folióes da sangueira, navalhistas e tombos-certos, que a polícia teve a necessidade de proibir a fantasia de diabinho a quem fosse maior de 12 anos. A fantasia, porém, estava desmoralizada, o crime aviltara o disfarce, e ela, desde 1885, entrou a decair [...] (FON-FON! 24/2/1911).

Na década de 1920 era raro ver alguém com esse tipo de traje na rua. A quase ausência dos diabretes nos periódicos, antes dignos de nota, é um sintoma do seu desaparecimento. $\mathrm{O}$ diabinho se tornou uma ameaça e um perigo à ordem dominante, sendo combatido de modo inexorável. Quem estava por trás da fantasia, segundo a percepção do cronista, eram "negralhóes", "mulataço", "rebotalho de bodegas e cortiço", qualificados como "assassinos amadores", "gentalha de eleições”, “embrutecidos dos vícios", "horda de bandidos" e "hóspedes de calabouços". Embora o texto procurasse condenar a vestimenta alegórica pelo uso que alguns capoeiras faziam dela, é a gente pobre e mestiça que está sendo o tempo todo atacada e apontada como perigosa e ameaçadora. Tanto assim que não é somente a fantasia em si que está sendo condenada; os célebres cordóes carnavalescos, eminentemente uma manifestação da cultura popular, são pensados sob a mesma perspectiva: a partir de expressóes como "foliōes da sangueira" e "navalhista”. Conforme Cunha, com a proibição de máscaras avulsas, em 1890, a alegoria passou a ser permitida apenas nos bailes e cortejos das sociedades carnavalescas. A historiadora comenta que a repressão às figuras endiabradas encontrou "seu ponto culminante numa estranha prática exorcista adotada pela polícia da corte em 1883”, quando os diabos, na freguesia de Santana, foram revistados e tiveram as suas caudas cortadas (CUNHA, 2001, p. 39).

Acredita-se que não haja nessa ação policial nenhum ritual para expulsar o diabo, e Dip. nos dá uma pista para o verdadeiro sentido do procedimento policiesco. O cronista relata que o grande rabo, outrora preenchido inofensivamente com algodão e estopa desfiada, tinha se transformado em armas, numa "máquina de guerra". Isso porque as caudas passaram também a ser revestidas com areia, e algumas eram cobertas de pontas de pregos. O rabo deixou de ser um simples ornamento e brincadeira, adquirindo outras funções, sendo usado como instrumento de provocação, combate ou contenda. E nem os comerciantes e as "negras quitandeiras" escapavam de levar umas esbordoadas de vez em quando. $\mathrm{O}$ cronista J. B. ratificou o fato no artigo "O carnaval de outrora, o carnaval de hoje", na Gazeta de Notícias (3/3/1919, p. 3). No texto ele explica que a extremidade do rabo era aberta com a finalidade de ferir o adversário indistintamente, principalmente quando havia encontros entre facções de capoeiras ${ }^{3}$. Além disso, alguns acessórios da fantasia eram utilizados para esconder armas, como a navalha, que ficava oculta num canudo de papelão, representando a enorme língua da carantonha.

\footnotetext{
${ }^{3} \mathrm{O}$ fato também pode ser confirmado na crônica de J. Verin, de 1886, publicada na Revista Ilustrada. O cronista informava que na "longa cauda satânica" se escondia às vezes uma navalha. Cf. NEPOMUCENO, 2011, p. 145.
} 
Decerto, o carnaval se mostra um campo de tensão e de luta pelo uso do espaço festivo, ainda mais energizado com o preceito de diversão elaborado pelas elites. A fantasia mefistofélica não faria parte do parâmetro civilizatório, tornando-se uma simbologia carnavalesca de oposição à nação projetada. Quer na representação barretiana, quer na dimensão histórica, ela se apresenta como tática, uma vez que é assinalada pela circunstância e pela esperteza, por uma ação fora de um lugar determinado, que se realiza por meio de lances e ocasiốes (CERTEAU, 2014, p. 94-95).

A indumentária, enquanto representação, está repleta de códigos que podem indicar o estado e o grupo social de uma pessoa, sinalizar para certas recordaçóes e imagens de batalhas. Como explica Stallybrass, a roupa é "ricamente absorvente de significados simbólicos", um tipo de material no qual as "memórias e as relaçôes sociais são literalmente corporificadas” (STALLYBRASS, 2012, p. 12-16). Assim, pensar sobre a vestimenta consiste em refletir, também, sobre poder e posse, sobre como os valores assumem a forma de roupa.

Na crônica "Máscara de todo ano" (A NOTÍCIA, 27/2/1908, p. 3), João do Rio percebe com agudeza o significado das roupas como marca identitária. Para o cronista, a vestimenta seria uma expressão da personalidade, sendo elucidativa das relaçóes e imbricaçóes sociais. Em época de folia, a indumentária ou a fantasia poderia ser reveladora de um desvio ou variação psicológica do ser. Assim, a máscara que esconde o rosto também o revela. Se o carnaval é uma crise de loucura e de identidade, cada um vestiria a fantasia que melhor the coubesse, expressando seu eu mais interior. Seguindo tal lógica, João do Rio delineia para cada grupo social um tipo de mascarada:

No máscara isolado [sic] há todo um tratado de patopsicologia. Um homem que trabalha o ano inteiro para se vestir de "princez" ou de "rei de diabos", e que sai por aí convencido na fatiota multicor, não pode ser muito certo, e um pobre rapaz, capaz de se fantasiar de "Pai João" e de tentar fazer espírito não é um prodígio de sensatez. Alguém mesmo já descobriu que a fantasia corresponde quase sempre a pequena racha que o tipo tem na mioleira [sic] ou a qualidade predominante da sua alma, contando os dominós pela hipocrisia, os princezes [príncipes] pelo efeminamento, os reis dos diabos pelo desvairamento delirante, os palhaços pela gente sem personalidade complacente [...].

- não há um rei dos diabos que não seja capoeira valentíssimo, um princez sem languores femininos, e repara no grande número de mulheres alegres usando as roupas de palhaço que elas dominam de clovis... (p. 3).

Nesse sentido, Joáo do Rio vincula um caráter psicológico para o uso da fantasia, como se esta fosse expressão de uma natureza humana. Remetendo a um imaginário social e preconceituoso de seu tempo, o escritor afirma que a alma do negro estaria associada à re- 
presentação do rei dos diabos. Embora a presença do negro não esteja agregada diretamente na crônica, ela se expressa pela articulação que o cronista elabora entre os termos "diabo", "capoeira" e "valentíssimo".

Cumpre destacar que nem todo capoeirista era negro ou de condição social pobre. Conforme Dias (2001, p. 97), havia figuras políticas importantes que praticavam o esporte, a exemplo do barão do Rio Branco e de Floriano Peixoto. O episódio mais famoso envolvendo pessoas ilustres com o desporte foi o de Juca Reis, filho do conde de Matosinho, que era proprietário do jornal $O$ Paiz. O rapaz teria sido condenado ao exílio pelo chefe de polícia, Sampaio Ferraz, durante o governo provisório da República, acusado de capoeiragem e ligaçóes monarquistas.

A imagem negativa da capoeira só começou a ser modificada a partir de 1930, com o Estado Novo varguista, que foi marcado pela centralização do poder político e cultural. Nesse campo, promoveu a valorização de elementos vistos como nacionais e populares. A capoeira, o samba e o carnaval se tornaram expressão de uma identidade brasileira em contraponto à produção cultural da "Primeira República", que investia em hábitos e costumes importados de países europeus. Quebrando a imagem estrangeira em que o "velho" sistema republicano tanto se espelhou, Vargas buscou unificar uma ideia de povo e de nação, espelhando aquilo que ele considerava brasileiríssimo: as manifestações folclóricas, as músicas e danças de expressão afrodescendente (ABREU e GOMES, 2009).

Posto isso, certas charges publicadas em revistas também fizeram essas comparaçóes entre a fantasia de diabo e o negro, dando destaque à enorme língua, ao rabo do diabinho e ao seu uso como instrumento de arma. Para ilustrar essa discussão, selecionamos alguns desenhos que foram publicados na revista Fon-Fon!. Eles circunscrevem nos traços caricaturais o imaginário social em torno da vestimenta de diabinho. Como explica Marcos Silva (1985/1986, p. 56-57), o humor visual é produtor de prazer e fascínio em razão da "força de suas sínteses críticas sobre diferentes assuntos”, assumindo, em determinado momento, intensos sentidos políticos. Ademais, "o desenho de humor opera com a colocação de valores e significaçóes em crise, realizando deslizamentos na estruturação de tais valores e significaçóes para desnudar algumas de suas dimensóes ocultas”. Mas essa operação varia conforme os projetos artísticos, culturais e políticos. Devemos dizer que a representação humorística analisada aqui parte de um ângulo conservador, associando a fantasia ao pobre, ao negro e à violência - imagem síntese que as elites republicanas sustentaram desde o século XIX e ao longo do século XX.

Nessa charge, intitulada "Momice triste", a personagem carnavalesca é levada pela cauda por um policial. Seu tom abatido é acompanhado e testemunhado por três figuras populares e fantasiadas: um menino vendedor de jornal, um Pai João e uma mulher negra mascarada de arlequina. Nesta e no diabo, a imagem do negro aparece por meio de certos estereótipos: lábios grossos e cabelos crespos. A pobreza das personagens é esboçada pelas fantasias rasga- 
Figura 1: Fon-Fon! Rio de Janeiro, ano V, n. 8, 24 de fevereiro de 1911.

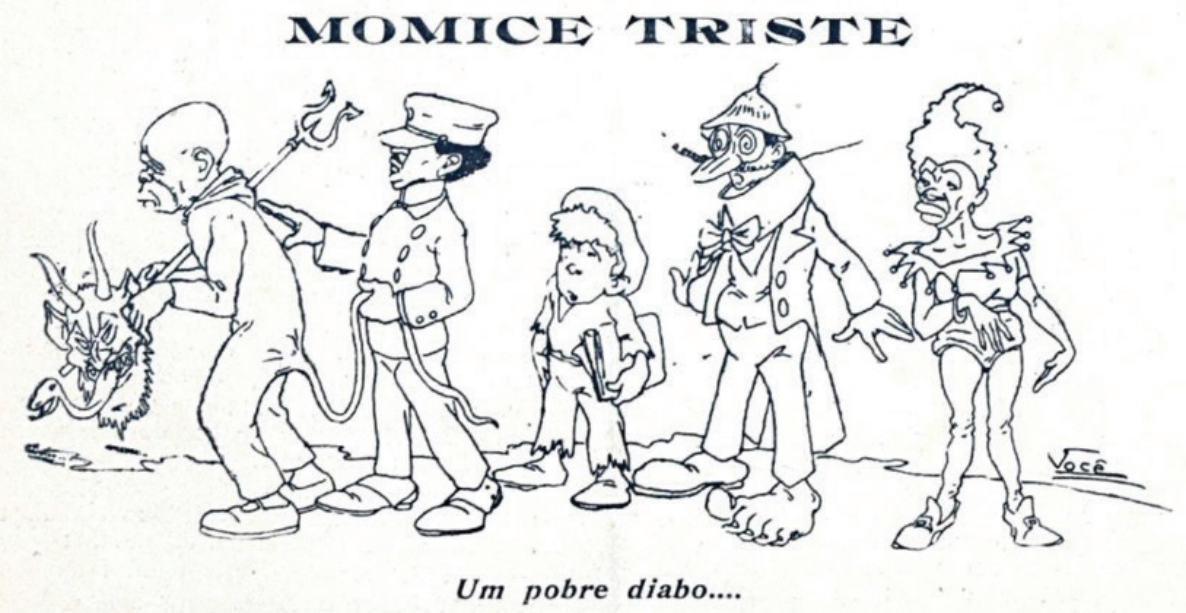

Fonte: Biblioteca Nacional

das e desajustadas. O desenho também revela, por meio da presença da polícia, a perseguição que os negros e os pobres experimentavam na insistência de usar a alegoria. É representativo como os outros mascarados observam o acontecimento - a expressão dos olhos, das bocas e das mãos demonstram empatia pelo preso, conferindo um ar triste para cena. Para o agente policial, a roupa, a máscara medonha, o tridente comprido e afiado eram signos de perigo, podendo ser um disfarce para se cometer delitos, ainda mais porque quem estava por trás da máscara era um homem negro. Todavia, o chargista ${ }^{4}$ elabora um contraste no quadro, pondo em oposição a autoridade e as demais figuras. Para estas, a atitude policialesca parece injustificada, pois assim como o grupo, a criatura endiabrada estava só se divertindo.

É expressivo o modo como a roupa alegórica apreende percepções diversas e múltiplos significados, sendo interpretada e usada distintamente, conforme as diferenças e os limites de classes, a proporção do poder, o lugar cultural e histórico. Enquanto as elites cariocas e a polícia consumiam a fantasia como uma representação perigosa, uma prática da violência e como "coisa de negro", os marginalizados fabricavam outros sentidos, dando usos e funçóes plurais, que iam desde a diversão, a teatralização e a irreverência a um valor opositor e uma espécie de armadura. Não é completamente incoerente e precitada a imagem de perigo que os cronistas e chargistas atribuíram à vestimenta. Mas é preciso interrogar: perigo para quem? Quem se sentia incomodado e ameaçado com a presença encarnada dos diabinhos?

A indumentária carnavalesca realmente tinha uma força contestatória, na insistência de seu uso e no enfrentamento da autoridade. $\mathrm{O}$ humor, a impertinência, a performance endiabrada e o improviso são artifícios que provocam, ofendem, criticam e póem em dúvida a ordem estabelecida. Em tempos de carnaval, os diabretes, com suas diabruras, poderiam se

\footnotetext{
${ }^{4}$ Não foi possível identificar o chargista que assinava com a alcunha "você".
} 
tornar uma ameaça para a elite de cartola que desejava ir às ruas, assim como foi o entrudo com suas bisnagas de "água servida”. Porém, não era apenas o poder público e o burguês que eram desafiados pela via do lúdico, da galhofa e da ousadia, sendo atacado, do mesmo modo, antigos adversários particulares ou aqueles mais eventuais.

É salutar informar que a fantasia também poderia ser usada para atos delituosos, como pequenos roubos, navalhadas, brigas e distúrbios. No século XIX, há vários relatos em jornais que comentam sobre indivíduos ou grupos, fantasiados de diabinho (entre eles escravos), que andavam pelas ruas da cidade carioca "fazendo furdunço" e cometendo crimes (NEPOMUCENO, 2011, p. 104-105). A própria confecção do traje, em alguns casos, adquire uma função combativa, à medida que a cauda poderia servir como arma e a máscara como suporte para guardar facas e outros instrumentos cortantes. Não é igualmente incongruente que turmas de capoeiras também portassem a alegoria, valendo-se dela com tática de conflito. Mas devemos enfatizar que tal vestimenta não era a única a ser empregada em açóes ilegais ou práticas subversivas. Embora associada a negros e capoeiras, ela era bastante popular entre os indivíduos pobres, brancos e de outras nacionalidades (CUNHA, 2001, p. 38).

Em suma, o que queremos dizer é que a roupa diabólica, de matriz europeia, vai agregando diversos valores e ressignificados. No Brasil, ela não permaneceu como um signo inalterado e, muito menos, como uma entidade marcada pela violência, conforme a interpretação de parte de alguns cronistas do Império e da República. Esses intelectuais intentaram construir uma "tradição seletiva", termo empregado aqui a partir da definição de Raymond Williams, em que "a partir de toda uma área possível do passado e do presente, certos significados e práticas são escolhidos e enfatizados, enquanto outros significados e práticas são negligenciados e excluídos” (2011, p. 54). Eles comunicaram uma história da alegoria, compreendendo as misturas culturais incorporadas, particularmente de origem afro-brasileira, como características negativas e delituosas. Escrevia um cronista: "e como seria deliciosa a alegria do carnaval se lhe tirassem essa expressão externa de folia do interior da África!" (FON-FON!, 7/3/1908).

Devemos ressaltar que nem toda figura do diabo era negada pelas elites, pois estas também se apropriavam do disfarce. Isso decorre porque o diabo compreende todo um imaginário judaico-cristão. Foi na Idade Média que a imagem tomou força simbólica, apresentando-se como uma entidade meio humana e meio animal. O Renascimento irá acentuar ainda mais esse retrato grotesco, e a literatura romântica do século XIX transformará Satã no símbolo da vida alegre (BRANDÃO e MAGALHÂES, 2012). A figura diabólica era compartilhada por todo o mundo ocidental. Os afortunados da República brasileira se apropriavam do mito, comprando máscaras caríssimas, nas lojas da rua do Ouvidor. A fantasia só começou a personificar os horrores do carnaval europeizado quando se popularizou entre os afrodescendentes (CUNHA, 2001, p. 37). É Lima Barreto quem remonta para o seu pre- 
sente outro valor simbólico da roupa de diabinho, pondo-o em disputa na memória coletiva do carnaval do começo do século XX.

Outra personagem também chama atenção na charge em análise: a imagem de Pai João. Tal figura dramática é igualmente popular na festa foliônica, apresentando-se geralmente como um copeiro de casaca e maltrapilho. Segundo o cronista Dip., a fantasia se resumia em besuntar a cara de pixe, usar trajes velhos e imundos e manejar uma vassoura velha pelas ruas da cidade (FON-FON!, 24/2/1911). Como não se precisava gastar dinheiro para se vestir dessa forma, qualquer pessoa podia se tornar esse tipo singular. Era o carnaval barato. Abreu (2004, p. 235-276) explica que essa personagem ironizava e remetia às problemáticas formativas da sociedade brasileira, conectada intimamente com a história da escravidão e com as lutas pela liberdade.

Abreu investigou, entre os anos de 1880 e 1950, várias narrativas sobre Pai João nas canções, poesias e contos populares, que foram registrados por diversos folcloristas, entre eles Arthur Ramos, Théo Brandão e Câmara Cascudo. A historiadora observou que em torno dessa representação gravitam amplas intrigas e enredos, o que torna questionável as versóes mais conhecidas sobre ela: negro, idoso, bom escravo, passivo, dócil, obediente e preguiçoso. Para além dessa caricatura, verificam-se no seu folclore denotaçóes mais abrangentes ligadas não somente à submissão e à dominação, mas também à subversão, à rebeldia e à negociação. A figura encerraria múltiplas "identidades e possibilidades dos homens negros durante a escravidão e no período pós-emancipação” (p. 238). Na sua variante mais ousada, o velho negro apresenta um poder de ação, mostrando-se trapaceiro, esperto e vingativo; revela-se ainda crítico e irônico em suas cançóes, no que tange ao trabalho escravo e à dominação senhorial.

É significativo que na Figura 1 Pai João apresente os traços brancos e já não use graxa no rosto para indicar a sua cor e sua condição escrava. Por si só, a imagem não sintetiza a história dos negros no Brasil, no sentido cultural e político, na luta pela liberdade. Nas charges, publicadas pela Fon-Fon! ${ }^{5}$ no começo da República, percebemos o embranquecimento do desenho, ainda que haja registro fotográfico de Pai João com pixe na cara. Da antiga personagem, os cartunistas se restringiram a pintar uma figura velha e solitária, de ar bondoso e cansado, vestida com paletós e calças em farrapos, e cartola desfeita. É difícil entender o motivo pelo qual esse símbolo foi se tornando branco, mas podemos esboçar algumas hipóteses. Talvez essa alteração esteja relacionada à sua popularização e ao custo mínimo da fantasia. $\mathrm{O}$ uso da figura se estendeu também para uma representação bem mais ampla na vida carnavalesca, atendendo a diversos aspectos da marginalização, seja de homens brancos, seja de negros e/ou pobres. Na República, o disfarce, ultrapassando a problemática racial, parece ser também emblema de outra categoria social, vale dizer que bastante perseguida pelo regime e cada vez mais crescente na cidade carioca: os mendigos.

\footnotetext{
${ }^{5}$ Ver as charges publicadas na revista Fon-Fon! Rio de Janeiro, ano III, n. 8, 18 fev. 1909.
} 
Pai João encarnava a precarização da sociedade carioca durante os anos iniciais da República, marcada por um processo inflacionário crônico que afetava a vida cotidiana de uma massa de trabalhadores: operários de fábrica, vendedores ambulantes, carroceiros, lavadeiras, pequenos comerciantes e funcionários do comércio fixo, acanhados servidores públicos, policiais de baixa patente, e assim por diante. Todos foram atingidos pelo desemprego, pela carestia dos aluguéis habitacionais e pelo alto custo dos gêneros alimentícios de primeira necessidade e até mesmo a sua escassez.

A crise social era tão profunda e desesperadora que proliferaram casas de agiotagem, e a população mais desprovida passou a penhorar quase tudo o que possuía, inclusive objetos íntimos: roupas, fronhas, materiais de cozinha como garfos e facas etc. Relatos de suicídio "por atraso de vida" se tornaram corriqueiros nos jornais da época; cartas anônimas de setores populares, de tom ameaçador e crítico, eram publicadas na imprensa; quadrinhas e versos sobre a carestia da vida eram cantadas em rodas de samba, na festa da Penha e no carnaval. Em 1914, para controlar o abuso no valor das mercadorias e evitar uma possível revolta popular, a prefeitura do Rio de Janeiro, em conjunto com alguns empresários, decretou o tabelamento dos preços dos alimentos, mas essa postura não conseguiu diminuir a especulação no custo dos gêneros alimentícios, além de esbarrar no interesse e discurso empresarial da liberdade de comércio (SANTOS, 2018).

Nessa circunstância, cujo ponto culminante foi a Primeira Guerra Mundial e uma onda de greve que abalou o país entre 1914 e 1918, Pai João deixa de aludir, na visão dos cartunistas, apenas ao "bom e antigo escravo". A personagem passa a significar no período pós-abolição e republicano as classes pobres e remediadas que foram afetadas pela crise social e econômica do novo sistema político. Cada vez mais os Pais Joóes vão se assemelhando a outra figura caricatural, também assinalada pela pobreza e pelo descaso político, o "Zé Povo".

Aliás, durante o carnaval, o "Zé Povinho", sem nenhum tostâo, adotava o velho maltrapilho como fantasia possível para brincar nos três dias de folia. Foi por esse ângulo que o desenhista Kalixto pintou tal representaçáo (figura 2). A legenda da caricatura mostra o real desejo de "Zé Povo": sair na festa de encarnado e tridente, ou seja, vestindo a sua roupa de diabinho, quem sabe para fazer qualquer tipo de diabrura. Tal alegoria, aliás, ajudava a guardar o anonimato do mascarado, já que as vestes cobriam o rosto e o corpo, criando opçóes para açôes diversas. A charge remete às possibilidades encontradas pelos pobres para se divertirem no período carnavalesco, que ocorre num contexto assinalado pela falta de dinheiro e pelo alto custo de vida, com os preços dos alimentos e de outras mercadorias inflacionadas. Em meio à crise financeira, a gente comum usa da criatividade e do improviso para brincar no carnaval, utilizando-se de sua própria pobreza e precariedade - roupas velhas e rasgadas - para se fantasiar. A miséria aí surge como metáfora!

O que notamos é que certas fantasias, de forte atração popular, estavam vinculadas à memória que tratam da história e da cultura negra no Brasil, e que tocam fundo nos signi- 
Figura 2: Fon-Fon! Rio de Janeiro, ano III, n. 8, 18 fev. 1909.

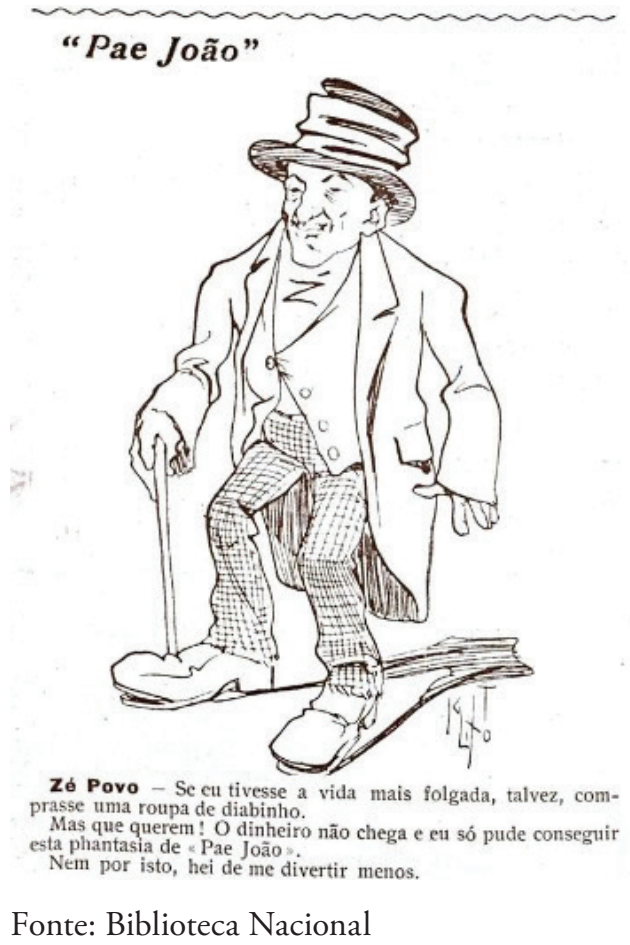

ficados e percepçóes da escravidão, assim como nas alternativas diretas e indiretas de lutas. Não era só o diabinho ou Pai João que estavam associados aos negros. Do mesmo modo, outra figura de sucesso dos carnavais cariocas foi apreendida pelo viés racial. Era "o velho"! Ele andava arrastando os pés, sua vestimenta era feita de veludo, segurava um enorme cajado de papeláo dourado, portava um grande caráo de velho e uma luneta, também de papeláo dourado ou prateado. Segundo uma crônica da Fon-Fon! (20/2/1914), sem assinatura, essa representação entrava em circulação nas ruas acompanhada quase sempre de um bando de diabinhos. Às vezes, formava-se uma roda de diabos com dois velhos ao centro, dando início a danças, cantigas e palmas, que poderiam terminar numa luta de capoeiras. Os velhos eram considerados experientes capoeiristas.

Voltando às charges que satirizam a fantasia de diabinho, o chargista O. I. S., pseudônimo de Raul Pederneira, também elabora uma caricatura bastante emblemática (figura 3). O personagem mascarado segura o rabo como se fosse uma arma, enquanto aborda ameaçadoramente um cidadáo comum. A presença do diabrete parece assustar o homem, que é caracterizado com as pernas abertas e os braços suspensos, como se estivesse sendo assaltado ou esperando uma ação delituosa. No entanto, a investida do fantasiado não passava de uma brincadeira de carnaval, que se torna esclarecida por meio do diálogo travado entre os dois indivíduos. O chiste se dá na pergunta do diabinho: "você tem enchimento?". Tal questionamento faz alusão ao hábito de enxertar o rabo com material grosseiro e pontiagudo. 
Figura 3: Fon-Fon! Rio de Janeiro, ano II, n. 48, 7 mar. 1908.

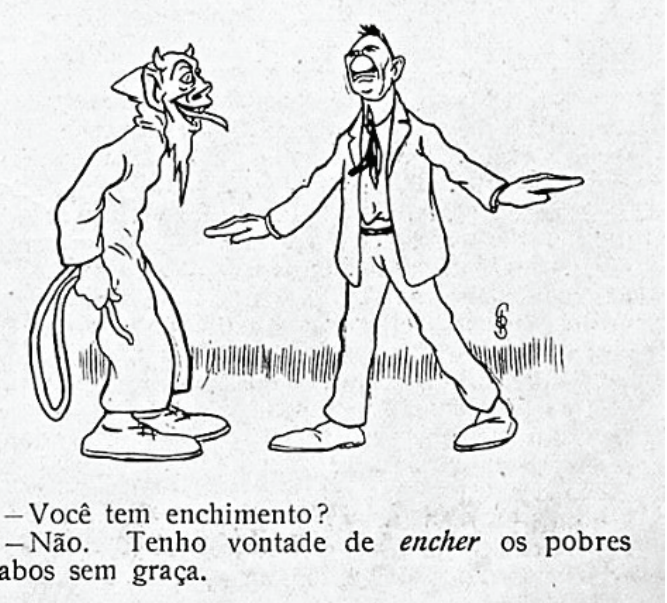

Fonte: Biblioteca Nacional

Hélios Seelinger ilustra, na Figura 4, igualmente um sujeito endiabrado que aparece sozinho, envolto em sua cauda enorme, que está presa entre as duas mãos. O desenho acompanha, na realidade, uma crônica sobre o carnaval intitulada "Uma ideia do José Gomes". Trata-se das peripécias carnavalescas de um pai de família respeitado e de grande prestígio social. Nesse enredo, não se faz nenhuma referência à fantasia diabólica, esta só ganha evidência pela ilustração. Na caricatura, a maneira como o rabo é agarrado, sendo levantado até a altura do rosto, é bastante expressiva. Há nessa postura não apenas um modo ostensivo, mas também uma atitude de força e orgulho. A cauda é, portanto, um objeto de poder e de luta. É significativo que as três representaçôes lembrem, em demasia, a descrição que os cronistas e o próprio Lima Barreto fizeram do molde da fantasia. Todavia, os sentidos que a alegoria adquire diferem entre os chargistas, cronistas e o literato.

Figura 4: Fon-Fon! Rio de Janeiro, ano III, n. 8, 18 fev. 1909.

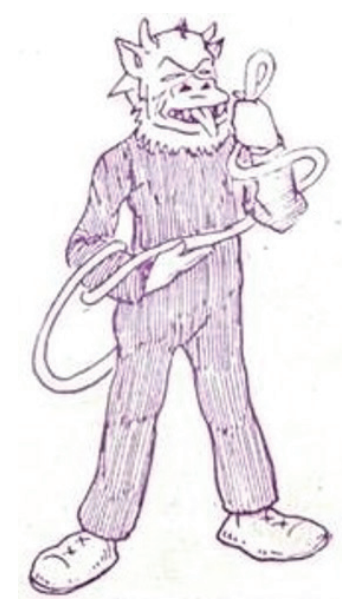

Fonte: Biblioteca Nacional 
Os cartuns, além de sinalizar para um evento histórico, acenam para uma memória cultural, que se imiscui de muitos imaginários. Embora, na Figura 1, haja uma certa identificação do chargista com o mascarado, impedido de brincar no carnaval, as reminiscências que brotam do traçado são de aspecto negativo. $\mathrm{O}$ mascarado pode ser um capoeira, na medida em que se evidencia a sua cor negra, apontada pelas linhas caricaturais. Essa lógica é seguida pelos outros desenhistas, quando representam o diabinho como alguém que pode ser interpretado como potencialmente criminoso (Figuras 2, 3 e 4). Lima Barreto, porém, inverte o símbolo dominante, atribuindo um sentido distinto. A fantasia ainda continua objeto de diversão foliônica, mas passa a ser também um instrumento de briga. Contudo, seu adversário não é o cidadão comum, mas sim as ideias e os chavôes racistas.

A indumentária como construção identitária já foi observada por Machado de Assis nos contos "Capítulo dos chapéus" (1998) e "O espelho" (1998). No primeiro, o estilo e o tamanho do chapéu remetem não apenas às classes sociais a que pertencem os indivíduos, aludindo igualmente para sua visão de mundo. A teoria da personagem Conrado Seabra sobre o acessório é sintomática de uma sociedade em que o externo é também a extensão do interno: "o chapéu", diz ele, "é a integração do homem, um prolongamento da cabeça, um complemento decretado ab eterno; ninguém o pode trocar sem mutilação" (ASSIS, 1998, p. 401-410). Desse modo, a cartola e a casaca representavam o homem tradicional e austero, ligado ainda a um tempo imperial (no caso, o pai da personagem Mariana); o chapéu baixo, leve e simples era indicativo de um indivíduo moderno, com pensamento liberal, o homem novo (o próprio Conrado); já o chapéu grande e cheio de plumas aludia à mulher elegante, rica e ambiciosa (a figura de Sofia). No segundo conto, o protagonista Jacobina transfere para o seu uniforme de alferes o sentido de sua existência. A farda era a sua segunda alma. Sozinho na fazenda de sua tia, distante das relaçóes sociais aparentes, metaforizadas pela vestimenta, Jacobina não reconhecia a si próprio. Seu reflexo no espelho era vago, difuso e esfumaçado. Um fantasma. Sua imagem só ganha corporeidade quando põe o uniforme. Só assim, ele consegue se sentir em paz consigo mesmo.

No que tange a Lima Barreto, mais do que um valor identitário, a roupa é expressão política e reivindicatória, uma vez que se busca por meio da fantasia assegurar a dignidade e erguer um campo de batalha. $\mathrm{O}$ autor trouxe para a ficção, através das diabruras de um menino negro, vítima do preconceito racial, os feitios polissêmicos da vestimenta, desvelando o aspecto marginal, o entretenimento e o conflito social, tudo imbuído no apetrecho alegórico. Portanto, a fantasia do diabo, o tecido na qual ela é confeccionada, assinala para uma história do carnaval popular, marcada por opressões e resistências que ultrapassavam os três dias de festa. A roupa de diabinho compreendia, de fato, um poder de luta.

Devemos enfatizar que a memória foliônica ganha novo sentido no universo literário barretiano. A indumentária diabólica está ainda associada à figura do negro e do pobre no conto. No entanto, diferentemente das reminiscências de Dip., J. B., João do Rio e das 
charges dos cartunistas aqui analisados, que apresentam imagens negativas e sedimentadas, Lima Barreto constrói uma lembrança positiva. Não é o capoeira, o bandido ou o assassino que portam a máscara, mas uma criança cheia de sonho e inocência. As características de Zeca, "pretinho", "pele de veludo", "carapinha sempre aparada", "roupas sempre limpas" (BARRETO, 2010, p. 146) contrapóem-se às representaçóes dos outros cronistas, cuja alegoria é agregada a "negralhóes" e "embrutecidos", que se velam e desvelam por detrás do disfarce. Lima Barreto elabora outra imagem do negro, retirando os recursos imagéticos de sujeira que foram associados a indivíduos e os grupos afro-brasileiros, como foi cantado e criticado por Gilberto Gil, na segunda metade do século XX.

Em face das diversas recordaçóes construídas em torno da roupa carnavalesca, o escritor faz uma aposta literária elaborando uma memória distinta do carnaval popular, pondo em disputa e em debate o significado que a fantasia de diabinho adquiriu no tempo. Desse modo, "O moleque" não é apenas uma representação artística de um acontecimento passado do Rio de Janeiro, mas um operador de sentido e uma escrita de resistência, uma vez que ordena e reconta uma parte da história cultural da cidade, fornecendo outra perspectiva, que abala o domínio e a homogeneização de uma certa reminiscência. Em outras palavras, o conto barretiano não expóe somente uma narrativa de luta; ele é um texto-ação, pois se insere dentro de um campo de batalha pela memória e pela justiça das classes inferiorizadas.

\section{Literatura e história}

A escrita de Lima Barreto tem uma característica peculiar - a sua invenção é sempre costurada com "fragmentos de verdade" . Isso não é gratuito, porque o seu fazer literário se constrói numa orientação política, de combate à miséria, ao preconceito racial e aos exploradores. Nesse sentido, a ficção e a realidade se misturam, cruzando-se de modo nem sempre claro. É preciso ir fundo na sua escrita, vasculhar as diversas interlocuçóes e os pontos formais que compóem o seu texto. É necessário analisar a sua produção como um historiador, detectando as vozes mais que imaginárias. Para tanto, é importante buscar outras fontes e refletir sobre os contextos, num procedimento comparativo.

Em outras palavras, a obra do autor não está somente entranhada de história por ser uma fabricação social de uma época. $\mathrm{O}$ acontecido, na sua complexidade e desdobramento, nos seus matizes culturais e materiais, é conscientemente introduzido em sua narrativa, participando como elemento formal. A vestimenta de diabinho, seu sentido carnavalesco, seus

\footnotetext{
${ }^{6}$ Expressão usada pelo historiador Carlo Ginzburg quando afirma que podemos detectar nos romances medievais testemunhos históricos sobre usos e costumes, "isolando na ficção fragmentos de verdade" (GINZBURG, 2007, p. 11).
} 
signos de luta não surgiram de uma imaginação pura. Esta não existe. Eles foram eventos reais. Não obstante, a literatura tem o poder de transfigurá-los, de brincar com a realidade, transgredindo as fronteiras entre o falso e o verdadeiro. $\mathrm{O}$ falso aqui não possui significado negativo, ele é o artifício ficcional, substância para a criação e o trabalho poético. A produção barretiana revela as forças de tensão na estrutura social, expondo uma narrativa que não aconteceu, mas aparece como possibilidade e crítica (SEVCENKO, 2003. p. 29).

Como afirmou Barbosa (1956, p. 16), Lima Barreto era um eminente memorialista a ponto de se tornar complicado avaliar, em seus romances e contos, os alcances da ficção e da realidade. Seu testemunho é tão importante, que não seria possível proceder a uma revisão do período republicano sem recorrer aos seus escritos. Lima Barreto era um colecionador de fontes jornalísticas e de periódicos. Desse conjunto de notas, tirava vários retalhos, que diziam respeito às histórias de vida de pessoas comuns, à ciência popular, aos anúncios de leilão de escravos, aos episódios políticos e ao cotidiano. Ele guardava com cuidado esses registros, fazendo anotaçóes e fixando as datas da publicação ${ }^{7}$. Essa documentação era usada para compor os seus romances e crônicas, sendo incorporada ao enredo. Nesse jogo, o real era ficcionalizado e a ficção era dada ao real. Um exemplo disso é o recorte que fez da Revista d'O Tempo, de 1894. No fragmento, fazia-se alusão a uma criança chamada Artur José dos Santos, cujo apelido era “Trinta-Réis”. O garoto ficou famoso durante a Revolta da Armada, pois estava sempre presente no momento em que o canhão era detonado, anunciando aos berros o tiro. Esse fato foi ficcionalizado e utilizado para confeccionar o livro Triste fim de Policarpo Quaresma (BARRETO, 1956).

No romance, o conflito é narrado pela perspectiva do habitual, do dia a dia, isto é, o quanto a população carioca foi afetada pela atividade bélica. Nesse sentido, o narrador vai descrevendo como o levante se tornou um ato festivo ou um divertimento para a cidade, em que homens, mulheres e idosos alugavam binóculos para enxergar melhor os bombardeios. Durante os ataques, o Passeio Público se enchia de gente. No cais Pharoux, os meninos vendedores de jornais, os engraxates e os quitandeiros ficavam à espera da queda das balas, correndo logo em seguida para apanhá-las. As crianças eram sempre aquelas que anunciavam o tiro do adversário, gritando: “- queimou!”. É nesse momento, então, que o caso do garoto Artur é recordado:

Houve um em Niterói que teve o seu quarto de hora de celebridade. Chamavam-no "TrintaRéis"; os jornais do tempo ocuparam-se com ele, fizeram-se subscriçôes a seu favor. Um herói! Passou a revolta e foi esquecido, tanto ele como a "Luci", uma bela lancha que chegou fazer-se entidade na imaginação da urbe, a interessá-la, a criar inimigos e admiradores (p. 235).

\footnotetext{
${ }^{7}$ Os papéis pessoais de Lima Barreto estão disponíveis no arquivo da Biblioteca Nacional e se encontram microfilmados. Cf. Rolo M5-503.
} 
Destarte, uma parte da obra barretiana é confeccionada com pequenas notícias e dísticos de jornais. Lima Barreto buscava nas leituras e análises dos fatos miúdos uma fonte para compreender os indivíduos no tempo. No seu texto "Anúncios... anúncios" (BARRETO, 2004, p. 243), essa percepção é posta de forma bastante consciente pelo cronista: "não sou humorista e, se leio os anúncios, é para estudar a vida e a sociedade. Os anúncios são uma manifestaçáo delas; e, às vezes, tấo brutalmente as manifestam que a gente fica pasmo com a brutalidade deles". Com essas informaçôes, o escritor refletia sobre "os conceitos e preconceitos" da época, anotando que certa vez observou um anúncio de aluguel de quarto com a particularidade que ele era destinado apenas a pessoas brancas ou a casal sem filhos.

Enfim, Lima Barreto não só trouxe a história para a sua produção ficcional, mas também era um animado leitor de alguns historiadores ${ }^{8}$ : Burckhardt, Hippolyte Taine, Plutarco, Thomas Carlyle etc. Sua literatura, além de documentar e testemunhar o vivido, trazia uma percepção analítica do mundo e dos homens. Isso não é novidade. Vale salientar o estudo da socióloga Paula Beiguelman (1981), que analisou o romance Numa e a ninfa e a sátira $A s$ aventuras do Doutor Bogóloff. A autora mostrou de maneira perspicaz as várias interlocuçôes literárias presente nas obras, examinando minuciosamente como elas dialogavam com os acontecimentos políticos do presente e do passado.

Para Ginzburg (2007, p. 17 e 91), a história se nutre não só do falso, mas igualmente da história falsa. As ficções são matérias do conhecimento historiográfico. Prescindir desse nexo é cair no fantasma do positivismo, "atitude de quem considera que a realidade é cognoscível diretamente, sem mediaçôes”. Assim, as mediaçôes literárias de Lima Barreto não obstaculizam a apreensão do social. Longe disso, seus artifícios artísticos são tramados conscientemente para que o leitor se aproxime da realidade evidenciada no texto de modo mais acentuado. Era esse o objetivo de sua escrita, o de ser uma arte missionária, forte o bastante para transmitir uma mensagem e para fazer crítica a um passado colonial que se mostra vivo e ativo: "ainda são as coisas de fazenda, com senzalas, sinhás-moças e mucamas, que regulam as ideias da nossa diplomacia; ainda é, portanto, o passado, daqui, dali, dacolá, que governa, não direi as ideias, mas os nossos sentimentos. É por isso que eu não gosto do passado" (BARRETO, 2004, p. 100). É contra esse tempo antigo e senhorial que o autor escreve, elaborando uma outra reminiscência para o presente vivido e a posteridade. Uma memória de resistência!

\section{Fontes documentais}

Biblioteca Nacional - revistas e jornais

Fon-Fon! Rio de Janeiro, ano II, n. 48, 7 mar. 1908.

\footnotetext{
${ }^{8}$ Oakley (2011) traz uma significativa dimensão dos historiadores que influenciaram Lima Barreto.
} 
Fon-Fon! Rio de Janeiro, ano III, n. 8, 18 fev. 1909.

Fon-Fon! Rio de Janeiro, ano V, n. 8, 24 fev. 1911.

Fon-Fon! Rio de Janeiro, ano VIII, n. 9, 20 fev. 1914.

Gazeta de Notícias, Rio de Janeiro, 3 mar. 1919. p. 3.

Jornal do Brasil, Rio de Janeiro, 26 jan. 1917. p. 10.

A Notícia, 27 fev. 1908, p. 3, microfilmado - Rolo PR - SPR 2515 1908/ jan. a mar./v. XV/ n. 1 a 78 .

Arquivo pessoal de Lima Barreto. Papéis pessoais avulsos, microfilmado - Rolo M5-503.

\section{Referências}

ABREU, Martha. Outras histórias de Pai João: conflitos raciais, protestos escravos e irreverência sexual na poesia popular, 1880-1950. Afro-Ásia, Salvador, v. 31, p. 235-276, 2004.

ABREU, Martha; GOMES, Ângela de Castro. Apresentação - A nova "velha” República: um pouco de história e historiografia. Revista Tempo (UFF), v. 13, n. 26, p. 1-14, 2009. Disponível em: http:/www.scielo.br/pdf/tem/v13n26/a01v1326.pdf. Acesso em: 12 jun 2018.

ASSIS, Machado de. O espelho. In: ASSIS, Machado de. Contos: uma antologia. São Paulo: Companhia das Letras, 1998. v. I.

ASSIS, Machado de. Capítulo dos chapéus. In: ASSIS, Machado de. Contos: uma antologia. São Paulo: Companhia das Letras, 1998. v. II.

BARBOSA, Francisco de Assis. Prefácio. In: BARRETO, Lima. Recordaçôes do escrivão Isaias Caminha. São Paulo, 1956.

BARRETO, Lima. O moleque. In: BARRETO, Lima. Contos completos. Organização de Lilia Moritz Schwarcz. São Paulo: Companhia das Letras, 2010.

BARRETO, Lima. A vingança (história de carnaval). In: BARRETO, Lima. Contos completos. Organização de Lilia Moritz Schwarcz. São Paulo: Companhia das Letras, 2010.

BARRETO, Lima. Literatura e política. In: BARRETO, Lima. Toda crônica. Organização de Beatriz Resende e Rachel Valença. Rio de Janeiro: Agir, 2004. v. I.

BARRETO, Lima. O convento. In: BARRETO, Lima. Toda crônica. Organização de Beatriz Resende e Rachel Valença. Rio de Janeiro: Agir, 2004. v. I.

BARRETO, Lima. Anúncio... anúncio... In: BARRETO, Lima. Toda crônica. Organização de Beatriz Resende e Rachel Valença. Rio de Janeiro: Agir, 2004. v. II. 
BARRETO, Lima. Triste fim de Policarpo Quaresma. São Paulo: Brasiliense, 1956.

BOSI, Alfredo. Narrativa e resistência. In: Literatura e resistência. São Paulo: Companhia das Letras, 2002.

BEIGUELMAN, Paula. Por que Lima Barreto. São Paulo: Brasiliense, 1981.

BRANDÃO, Eli; MAGALHÃES, Antonio Carlos de Melo. O diabo na arte e no imaginário ocidental. In: MAGALHÂES, Antonio Carlos de Melo et al. O demoníaco na literatura. Campina Grande: EDUEPB, 2012.

CERTEAU, Michel de. A invenção do cotidiano: artes de fazer. Tradução de Ephrain Ferreira Alves. 21. ed. Rio de Janeiro: Vozes, 2014.

CHEVALIER, Jean; CHEERBRANT, Alain. Dicionário de símbolos. Tradução de Vera da Costa e Silva et al. 9. ed. Rio de Janeiro: José Olympio, 1995.

CUNHA, Maria Clementina Pereira. Ecos da folia: uma história social do carnaval carioca entre 1880 e 1920. São Paulo: Companhia das Letras, 2001.

DAVIS, Natalie Zemon. Razóes do desgoverno. In: DAVIS, Natalie Zemon. Culturas do povo: sociedade e cultura no início da França Moderna. Tradução de Mariza Corrêa. Rio de Janeiro: Paz e Terra, 1990.

DIAS, Luiz Sergio. Quem tem medo de capoeira? Rio de Janeiro, 1890-1904. Rio de Janeiro: Secretária Municipal da Cultura et al., 2001.

GIL, Gilberto. A mão da limpeza. In: GIL, Gilberto. Raça humana. Rio de Janeiro: Warner Music Brasil, 1984. 1 LP, faixa 6. Disponível em: http://www.gilbertogil.com.br/sec_disco_ info.php?id=236\&letra\#. Acesso em: 18 abr. 2018.

GINZBURG, Carlo. O fio e os rastros: verdadeiro, falso, fictício. Tradução de Rosa Freire d’Aguiar e Eduardo Brandão. São Paulo: Companhia das Letras, 2007.

MAIA, Raul; PASTOR, Nelson. Magno dicionário brasileiro de lingua portuguesa. São Paulo: Editora DCL, 1995.

NEPOMUCENO, Eric Brasil. Carnavais da abolição: diabos e cucubis no Rio de Janeiro (1879-1888). Dissertação (Mestrado em História Social) - Instituto de Ciências Humanas e Sociais, Universidade Federal Fluminense, Niterói, 2011.

OAKLEY, R. J. Lima Barreto e o destino da literatura. São Paulo: Unesp, 2011.

PEREIRA, Leonardo Affonso de Miranda. A dança da política: trabalhadores, associativismo recreativo e eleiçóes no Rio de Janeiro da Primeira República. Revista Brasileira de História, São Paulo, v. 37, n. 74, p. 1-26, abr. 2017.

PEREIRA, Leonardo Affonso de Miranda. "O prazer das morenas": bailes, ritmos e identidades nos clubes dançantes da Primeira República. In: MARZANO, Andrea; MELO, Victor Andrade de (orgs.). Vida divertida: história do lazer no Rio de Janeiro (1830-1930). Rio de Janeiro: Apicuri, 2010. 
SALIBA, Elias Thomé. Raizes do riso: a representação humorística na história brasileira: da Belle Époque aos primeiros tempos do rádio. São Paulo: Companhia das Letras, 2002.

SANTOS, Poliana dos. O povo e o paraíso dos abastados - Rio de Janeiro, 1900/1920 (crônicas e outros escritos de Lima Barreto e João do Rio). Tese (Doutorado em História Social) - Faculdade de Filosofia, Letras e Ciências Humanas, Universidade de São Paulo, São Paulo, 2018.

SARTRE, Jean-Paul. Por que escrever? In: Que é a literatura? Tradução de Carlos Felipe Moisés. São Paulo: Ática, 1989.

SCHWARCZ, Lilia Moritz. Lima Barreto: triste visionário. São Paulo: Companhia das Letras, 2017.

SEVCENKO, Nicolau. Literatura como missão: tensôes sociais e criação cultural na Primeira República. 2. ed. São Paulo: Companhia das Letras, 2003.

SILVA, Marcos A. da. O trabalho da linguagem. Revista Brasileira de História, São Paulo, v. 6. n. 11, p. 45-61, set./fev. 1985/1986.

STALLYBRASS, Peter. A vida social das coisas: roupa, memória, dor. In: STALLYBRASS, Peter. O casaco de Marx: roupa, memória, dor. Tradução de Tomaz Tadeu. Belo Horizonte: Autêntica, 2012.

WILLIAMS, Raymond. Base e superestrutura na teoria da cultura marxista. In: WILLIAMS, Raymond. Cultura e materialismo. Tradução de André Glaser. São Paulo: Unesp, 2011. 